\title{
Peran Dakwah Melalui Media Cetak Untuk Pengembangan Masyarakat Islam (Studi Terhadap Peran Majalah Suara Hidayatullah Lampung) \\ Pajrun Kamil \\ IAIN Bengkulu \\ pajrunkamil@gmail.com
}

\begin{abstract}
Hidayatullah's voice magazine is an Islamic magazine managed by PT. Lentera Jaya Abadi, both of which are under the auspices of the Hidayatullah Mass Organization (ORMAS). Its presence has supported the missionary movement of the Hidayatullah Islamic Boarding School throughout Indonesia, especially conveying information about Islamic boarding schools programs to a broad audience. Along with the progress of the Hidayatullah Islamic Boarding School, the magazine became the largest and widest Islamic magaine in its distribution in Indonesia. The role of Hidayatullab's voice magazine in the development of the Islamic community is quite significant, as evidenced by the many representatives of the Hidayatullah pesantren, while the role of this magazine includes: as a communicator, motivator and facilitator. The focus of this research is how is the role of Hidayatullah's voice magazine in the development of Islamic society? What are the supporting factors and obstacles in developing Islamic society? The purpose of this study is to analyze the role of Hidayatullah's voice magazine in community development, and analyze what factors are supporting and inbibiting it. In this study the authors used qualitative research, it is hoped that with this method able to reveal facts in depth, researchers conducted structured and unstructured interviews with the resource persons namely the administrators of the Hidayatullah Voice Magazine and their readers. And supported by documentation data and direct observation. The conclusion of this study is First. The role of Hidayatullah Voice Magazine as a communicator is to communicate or socialize related to Islamic Community Development programs, as a motivator, which is to provide motivation to preachers in various remote areas, as facilitators, who also facilitate the preachers both within the Hidayatullah Community Organization. and other Islamic ORMAS in the process of developing Islamic societies. The two supporting factors of Hidayatullah's voice magazine in the development of the Islamic community are the presence of a network of militant cadres throughout Indonesia and have loyal readers. While the inhibiting factors are lack of funds to develop productive businesses and the lack of professional buman resources (SDI).
\end{abstract}

Key Words: The Role Of Dakwah, Prin Media, the Development of Islam 
176 | Jurnal Dakwah dan Komunikasi, Vol. 3 No. 2, 2018

\begin{abstract}
Abstrak
Majalah suara Hidayatullah adalah Majalah Islam yang di kelola oleh PT. Lentera Jaya Abadi, yang mana keduanya di naungi oleh Organisasi Massa (ORMAS) Hidayatullah. Keberadaannya turut mendukung gerakan dakwah Pesantren Hidayatullah di seluruh Indonesia, terutama menyampaikan seputar informasi program-program Pesantren kepada khalayak luas. Seiring dengan kemajuan Pesantren Hidayatullah, maka majalah tersebut menjadi majalah Islam terbesar dan terluas dalam penyebarannya di Indonesia. Peran Majalah suara Hidayatullah dalam pengembangan masyarakat Islam cukup siknifikan hal ini terbukti dari banyaknya perwakilan-perwakilan pesantren Hidayatullah, adapun peran majalah ini antara lain: sebagai komunikator, motivator dan fasilitator. Fokus penelitian ini adalah bagaimana peran Majalah suara Hidayatullah dalam pengembangan masyarakat Islam?apakah faktor pendukung dan penghambatnya dalam mengembangkan masyarakat islam? Adapun tujuan penelitian ini untuk menganalisis tentang peran Majalah suara Hidayatullah dalam pengembangan masyarakat, dan menganalisis factor-faktor apa saja yang menjadi pendukung dan penghambatnya. Dalam penelitian ini penulis menggunakan penelitian kualitatif, diharapkan dengan metode ini mampu mengungkap fakta-fakta secara mendalam, peneliti melakukan wawancara terstuktur maupun tidak terstruktur dengan para nara sumber yakni para pengurus Majalah suara Hidayatullah dan para pembacanya. Serta didukung oleh data dokumentasi dan observasi secara langsung. Kesimpulan penelitian ini adalah Pertama. Peran Majalah suara Hidayatullah sebagai komunikator yakni mengkomunikasikan atau mensosialisasikan terkait program-program Pengembangan Masyarakat Islam, sebagai motivator yakni turut memberikan motiviasi kepada para da'i yang berada di berbagai wilayah terpencil, sebagai fasilitator yakni turut memfasilitasi para da'i baik di internal ORMAS Hidayatullah maupun ORMAS Islam lainnya dalam proses pengembangan masyarakat islam. Kedua paktor pendukung Majalah suara Hidayatullah dalam pengembangan masyarakat Islam adalah dengan adanya jaringan kader militan di seluruh Indonesia dan memiliki pembaca yang loyal. Sedangkan paktor penghambatnya adalah kurangnya dana untuk mengembangkan usaha-usaha produktif dan minimnya sumber daya insani (SDI) yang professional.
\end{abstract}

Kata Kunci : Peran Dakwah Dakwah, Media Cetak, Pengembangan Masyarakat Islam

\title{
Pendahuluan
}

Islam adalah agama dakwah yang artinya Islam harus disebarkan kepada seluruh umat manusia. Dengan demikian umat Islam bukan saja berkewajiban melaksanakan ajaran Islam dalam keseharian hidupnya, melainkan juga harus 
menyampaikan (tabligh) atau mendakwahkan kebenaran ajaran Islam kepada orang lain.

Menurut Endang S. Anshari dikutip oleh Toto Tasmara mengatakan dakwah dalam arti luas ialah: "Penjabaran, penterjemahan dan pelaksanaan Islam dalam perikehidupan dan penghidupan manusia (termasuk di dalamnya politik, ekonomi, sosial, pendidikan, ilmu pengetahuan, kesenian, kekeluargaan dan sebagainya). ${ }^{1}$

Jelaslah, setiap muslim harus merasa terpanggil untuk melakukan prubahan atau (dakwah). Pasalnya, hadis tentang mengubah kemungkaran menjadikan pengubahan sebagai kewajiban yang dibebankan kepada siapa saja yang melihat kemungkaran. ${ }^{2}$

Mengenai cara atau metode berdakwah diserahkan kepada masing-masing individu, sesuai dengan keadaan lingkungan masyarakatnya. Dengan catatan tidak keluar dari ketentuan syariat dan nilai-nilai agama. Akan tetapi, kultur umat Islam dalam berdakwah selama ini lebih menonjolkan cara bil lisan, orasi atau pidato di atas mimbar. Metode dakwah adalah cara-cara yang dipergunakan da'i untuk menyampaikan pesan dakwah atau serentetan kegiatan untuk mencapai tujuan dakwah.Sementara itu, dalam komunikasi metode lebih dikenal dengan approach, yaitu cara-cara yang digunakan oleh seorang komunikator untuk mencapai satu tujuan tertentu.

Namun di zaman sekarang masyarakat mulai mempraktikkan dakwah bil qolam. Dakwah bil Qolam (dengan pena) merupakan strategi dakwah yang efektif, namun tidak bisa dipungkiri masih banyak da'i-da'i yang belum memiliki kemampuan dalam tulis-menulis, begitu juga dengan mad'unya masih lebih banyak yang suka mendengarkan. Sehingga dakwah ini masih terbatas pada kalangankalangan tertentu.

Hal ini dikarenakan, peradaban masa kini sering disebut sebagai peradaban masyarakat informasi.Informasi menjadi suatu komoditi primer bahkan sumber kekuasaan.Informasi dapat dijadikan alat untuk membentuk pendapat publik (public opinion) yang mempengaruhi dan mengendalikan pikiran, sikap, dan perilaku manusia. Hingga pada akhirnya, muncul sebuah anggapan bahwa sumber baru kekuasaan saat ini adalah "informasi di tangan banyak orang" (the new source of power is information in the hand of many), dan siapa yang menguasai media massa maka dialah pengendali atau penguasa dunia.

Tak heran jika sarana atau media informasi terus berkembang begitu pesat demi meraih kepentingan di atas.Media-media tersebut hadir merepresentasikan maksud, tujuan, dan target-target tertentu.Bagi khalayak ramai, kehadiran sebuah informasi tentu bisa menjadi sesuatu yang positif namun juga sebaliknya. Informasi terkadang membuat seseorang bergerak secara gegabah tanpa terlebih dahulu melakukan proses tabayyun yang cukup. Persoalannya menjadi semakin rumit ketika sebuah informasi atau berita negatif mendapatkan tempatnya di benak pembaca,

${ }^{1}$ Toto Tasmara, Komunikasi Dakwah, (Jakarta: Penerbit Gaya Media Pratama, 1997).

${ }^{2}$ Asep Samsul M. Romli, SIP, JURNALISTIK DAKWAH visi dan misi dakwah bil Qalam, (Bandung: Remadja Rosdakarya, 2003) . 05

${ }^{3}$ Walter Lippmann, Opini Umum, (Jakarta: Yayasan Obor Indonesia, 1994) . Xxii 
mempengaruhi dan mengendalikan gerak serta prilaku mereka.Inilah yang menjadi dasar analisa Lippmann. Menurut Lippmann, masyarakat menerima fakta bukan sebagaimana adanya, akan tetapi apa yang mereka anggap sebagai fakta; "kenyataan fatamorgana" atau "lingkungan palsu". Distorsi-distorsi tidak hanya datang dari faktor emosional dan kebutuhan ego saja, tetapi juga dari stereotip-stereotip, gambaran yang kita miliki tentang para tokoh figur publik, dan produk benda-benda.

Pada pembahasan ini, persoalan media sebagai alat untuk mempengaruhi massa lebih dominan. Bahkan ia mampu mencakup secara umum. Proses mempengaruhi massa justru dapat dilakukan melalui penerangan, edukasi, hiburan atau sebuah kelompok atau orang tertentu.

Ditinjau dari pendekatan ilmu media, maka isi dari media cetak sesungguhnya dapat di katagorikan kedalam dua hal; fakta dan opini. ${ }^{4}$ Fakta di sini adalah sesuatu yang bisa dilihat, diraba, dan dirasakan oleh setiap orang. Oleh karena itu, laporan faktual adalah laporan wartawan dari lapangan berdasarkan sesuatu yang dilihatnya atau kesaksian orang lain. Artinya ia betul-betul terjadi. Isi media cetak yang berdasarkan fakta adalah; berita.Karena bersifat faktual biasanya berita selalu dianggap objektif.Opini adalah pendapat atau pandangan tentang sesuatu. Karena itu opini bersifat subjektif karena pandangan atau penilaian seseorang dengan lainnya selalu berbeda, meski didasari fakta yang sama. Termasuk opini diantaranya; artikel, tajuk rencana, karikatur, pojok, dan surat pembaca. Sementara itu, antar Fakta dan opini terdapat apa yang disebut feature (karangan khas). Feature bukan karya fiksi melainkan tulisan faktual bergaya sastra sehingga amat menarik untuk dibaca dan terkadang mampu mengarahkan emosi pembacanya. ${ }^{5}$

Dalam hal ini opini publik dapat dikatakan sebagai target dalam penyampaian pesan. Akan tetapi, opini publik seperti apakah yang memiliki efektifitas ?.Oleh karenanya sebagian pakar komunikasi membedakan antara public opinon dan general opinion.Public opinion lebih tepat diartikan sebagai "pendapat khalayak" atau "anggapan khalayak.”Opini publik menurut Clyde L. King pakar publisistik pada Universitas Pensylvania adalah penilaian sosial (social judgement) mengenai suatu masalah.Opini publik bukanlah kata sepakat dari orang-orang publik.Opini publik dapat merupakan mayoritas pendapat, tapi bukan mayoritas pendapat yang dapat dihitung secara numeric menurut jumlah. Andaikan ada 49 persen dari suatu populasi menyatakan pendapat dengan tegas dan kuat, sedangkan 51 persen menyatakan pendapat dengan lemah dan setengah-setengah, maka opini yang 49 persenlah akan muncul sebagai kekuatan. Karena itu opini publik bukanlah numerical majorty, melainkan effective majority. ${ }^{6}$

Peran media sejatinya adalah untuk membentuk effective majority itu. Opini publik yang memiliki sifat efektif akan memiliki pengaruh yang kuat ditengah-tengah

\footnotetext{
${ }^{4}$ Aceng Abdullah, Press Relations; Kiat Berbubungan dengan Media Massa, (Bandung: Remaja Rosdakarya, 2001), 14

${ }^{5}$ Feature bisa mengandung unsure berita atau tidak. Feature berita adalah feature yang terpengaruh unsure waktu, yang berhubungan dengan peristiwa hangat yang menarik perhatian masyarakat. Biasanya cepat lekang dimakan waktu. Sementara feature human interest tidak punya nilai berita. Ia tidak memberikan informasi mengenai kepentingan umum yang vital. Lihat, Bambang Bujono (Ed.), Seandainya Saya Watawan Tempo, (Jakarta: ISAI dan Yayasan Alumni TEMPO, 1997), 100

${ }^{6}$ Adian Husaini, Penyesatan Opini; Sebuah Rekayasa Mengubah Citra, . xxvii
} 
masyarakat. Ia tidak hanya mengubah cara pandang seseorang terhadap sebuah persoalan, bahkan sangat mungkin mengarah kepada tahap perubahan prilaku sekalipun. Namun demikian sebuah opini publik yang efektif tidaklah terjadi begitu saja.

Bagaimana dengan masyakarat Islam, khususnya lembaga-lembaga dakwah saat ini, Majalah juga merupakan media yang sangat efektif untuk memberikan arahan, pemahaman dan pencerahan sepiritual terhadap anggotanya, bahkan masyarakat Islam.Karena bisa menyampaikan misi dakwah kapan dan di mana saja kepada pembaca. Bahkan lebih spesifik bisa menyampaikan misi dakwah sampai pada ruangan kamar tidur atau di kala berbaring dan bercengkrama dengan keluarga.

Media cetak yang peneliti maksud dalam kajian ini adalah Majalah suara Hidayatullah, yang dinaungi oleh ORMAS Hidayatullah atau Pesantren Hidayatullah, sebuah lembaga dakwah yang konsen pada program tarbiyyah (pendidikan) dan dakwah. Saat ini ORMAS Hidayatullah atau Pesantren Hidayatullah yang cikal bakalnya dari seorang penggagas Allahu yarham K.H. Abdullah Sa'id dari Sulawesi Selatan dan memulai dakwahnya dengan mendirikan Pesantren Hidayatullah di Balikpapan Kalimantan Timur telah memiliki jaringan di seluruh Indonesia dari Sabang sampai Meruke.

Menerbitkan media massa merupakan satu obsesi besar oleh KH. Abdullah Said.Menurut beliau yang paling mendesak saat itu adalah media cetak karena termasuk media da'wah yang sangat efektif.Dapat masuk langsung ke kamar-kamar, dapat dibaca sambil baring, dapat menyampaikan pesan kapan dan dimana saja kepada pembacanya. ${ }^{7}$

Maka setelah melalui persiapan yang panjang, pada 13 Mei 1982 nomor perdana Buletin Da'wah sebagai cikal bakal Suara Hidayatullah mulai terbit. Buletin ini dicetak sebanyak 500 eksemplar.Kemudian September 1986 terbit dalam bentuk majalah ukuran kecil setebal 88 halaman, tetapi mendapat teguran dari Departemen Penerangan (Deppen) karena belum mengantongi Surat Tanda Terbit (STT).Setelha delapan bulan keluranya izin penerbitan (STT) dari Deppen tahun 1986, majalah 'Suara Hidayatullah" terbit tepatnya pada tanggal 15 Oktober 1987.8

Sejak itu lah majalah tersebut terus berkembang, bahkan pada tahun 1995 sampai 1998 merupakan Tiras majalah mencapai puncaknya yakni terbit 70.000 exsplar setiap bulan. Dalam perkembangannya terus melakukan perbaikanperbaikan, sehingga dalam penyajian materi-materinya juga terus berkembang. Adapun isi-isi majalah tersebut dibagi ke dalam lima bagian, antara lain: Kajian dan Ulasan, warta, Tokoh, Jendela Keluarga, Lain-Lain.

Berdasarkan hasil survey yang ditampilkan dalam majalah tersebut pada edisi 03/XXI / Juli 2008-Jumadil Akhir 1429 / ISSN 0863-2367 bahwa pembacanya di seluru Indonesia antara lain: Wilayah Jawa dan sekitarnya 1, 28, 730 orang,

${ }^{7}$ Manshur Salbu, Mencetak Kader, Perjalanan Hidup Ustadz, Abdullah Said Pendiri Hidayatullah, 153

${ }^{8}$ Majalah Suara Hidayatullah, Tonggak-tonggak Sejarah majalah Suara Hidayatullah, Edisi khusus Milad 2008, 90 
Wilayah Sumatra 24. 770 orang, Wilayah Kalimantan 44, 030, Wilayah Sulawesi 50, 555 orang dan wilayah Papua dan Nusatenggara 8, 545 orang. ${ }^{9}$

Bila dilihat dari sisi umur maka para pembacanya antara lain: $52 \%$ berumur 20 - 40 tahun, $32 \%$ berumur 41 - 50 tahun dan $14 \%$ diatas 50 tahun. Jika dilihat dari pekerjaannya maka: $22 \%$ Wirasuasta, $37 \%$ PNS, $18 \%$ pegawai suasta, $12 \%$ mahasiswa dan pelajar dan $11 \%$ lain-lain. Sedangkan kalau dilihat dari tingkat pendidikannya antara lain: $27 \%$ SLTA, $40 \%$ S I, $33 \%$ Lain-llain. ${ }^{10}$

Sedangkan di Provinsi Lampung terdapat 700 orang pelanggan majalah suara Hidayatullah, menurut Mashuri Syah Abadi Distributor wilayah lampung, Majalah-majalah tersebut dibaca oleh kalangan menengah ke atas, mengingat Majalah ini cukup mahal, dengan harga 23.500 per exsplar. dan distribusikan di beberapa wilayah, antara lain: Bandar Lampung, Lampung Selatan, Bandar Jaya, Menggala, Lampung Timur dan Way Kanan. Lebih spesifik beliau menjelaskan bahwa majalah-majalah tersebut dijual dan dibaca oleh beberapa pejabat perusahaan suasta dan BUMN antara lain: Swiitindo Lampung, Gula putih Mataram, Gunung Madu, Indo Lampung Perkasa, PT. Pelindo, PT. Telkomsel, PT. Rindang 31, PT. Lima Saudara Prima dan beberapa tempat lain, baik secara pribadi maupun kolektif. ${ }^{11}$

Berdasarkan data-data di atas maka muncul pertanyaan peneliti, apakah media cetak (Majalah suara Hidayatullah) mempunyai peran dakwah dalam pengembangan masyarakat Islam? Dan apa saja yang menjadi factor pendukung dan penghambatnya dalam upaya pengembangan masyarakat slam? Maka pertanyaan ini masih perlu pembuktian dan pembahasan yang sangat mendalam, agar fenomena di atas dapat dijawab secara ilmiah.

Landasan Teori

Sumber utama materi dakwah adalah Al-Quran dan As-Sunnah.Dakwah merupakan aktivitas da'i dalam menyeru kepada mad'u untuk senantiasa mematuhi segala ketentuan dari Allah SWT dan Rasul-Nya, juga memberikan pencerahan mental spiritual agar kemudian menjadi lebih baik dari sebelumnya.

Dalam surah Ali 'Imron ayat 104 Yang artinya dan hendaklah ada di antara kamu segolongan umat yang menyeru kepada kebajikan, menyuruh kepada yang ma'ruf dan mencegah dari yang munkar merekalah orang-orang yang beruntung.

Dalam ayat ini Allah Subhanahu Wa Ta'ala memberikan mandat kepada sebagaian dari manusia untuk menjadi juru dakwah, dalam rangka menyerukan kebajikan. Yakni menyeru kepada yang ma'ruf dan mencegah kepada yang munkar.Da'i dalam menyampaikan misi dakwahnya dibutuhkan berbagai keilmuan, agar targetnya maksimal.

Juga dalam surah Ali 'Imron ayat 110 Allah berfirmanYang artinya: kamu adalah umat yang terbaik yang dilahirkan untuk manusia, menyuruh kepada yang ma'ruf, dan mencegah dari yang munkar, dan beriman kepada Allah. sekiranya ahli Kitab beriman, tentulah itu lebih baik bagi mereka, di antara mereka ada yang beriman, dan kebanyakan mereka adalah orang-orang yang fasik. Juga Allah

${ }^{9}$ Majalah Suara Hidayatullah, Profil Majalah Suara Hidayatullab tabun 2008, edisi 03/XXI / Juli 2008-Jumadil Akhir 1429 / ISSN 0863-2367, 16

${ }^{10}$ Ibid, 16

${ }^{11}$ MSA, distributor majalah Suara Hidayatullah, Wawancara tgl. 2 Agustus 2010 
berfirman dalam surah Al-Qolam Yang artinya Nun, demi kalam dan apa yang mereka tulis.

Nabi Salallahu 'alahi Wasallama bersabda: Yang artinya: barang siapa diantara kalian melihat kemungkaran, maka hendaklah ia merubah dengan tangannya, jika tidak bisa maka dengn lisannya, jika tidak kuasa dengan lisannya, maka dengan hatinya, yang demikian itu adalah selemah-lemahnya iman. (H.R. Muslim).

Hadis tersebut merupakan strategi perubahan social politik. Pada kenyataannya, selama ini terdapat tiga macam strategi yang diterapkan oleh ummat islam yang rujukannya hadis di atas; stuktural, kulturan dan mobilitas social. Mengubah dengan tangan berarti perubahan structural.Mengubah dengan lidah berarti perubahan kultural.Mengubah dengan hati berarti perubahan social tanpa usaha tertentu hanya menunggu waktu.

Dalam menyampaikan pesan dakwah tersebut dibutuhkan media, media masa, cetak, elektronik, sehingga pesan yang disampaikan lebih efektif dan tepat sasaran. Menyadari akan hal tersebut, maka dalam penelitian ini difokuskan pada media cetak sebagai media penyampaian pesan dakwah dalam mengembangkan masyarakat Islam.

Media beasal dari kata Latin "medium" (tunggal) "media" (jamak) yang secara harfiyah berarti: pertengahan, tengah, pusat. dengan demikian, menyebut "media" sudah berarti jamak, tidak perlu media-media. Sedangkan cetak arti harfiyah bahasa Indonesia "cetak" ialah cap, acuan, makna harfiyah ini belum memuaskan, karena itu kita masih perlu mengacu kepada kosakata bahasa Inggrisnya. Dalam bahasa inggris, cetak, yang berkaitan dengan produksi media cetak, ialah press. Press berarti: mesin untuk mencetak buku, media, surat kabar. ${ }^{12}$

Sehingga media disini adalah alat jalur komunikasi (massa), atau perantara yang menemukan seseorang dengan orang lain sehingga memungkinkan terjadinya komunikasi (komunikasi masa).

Selain itu media juga berarti alat atau wahana yang digunakan untuk memindahkan pesan dari sumber kepada penerima. Untuk itu komunikasi bermedia (mediated communication) adalah komunikasi yang menggunakan saluran atau sarana untuk meneruskan suatu pesan kepada komunikan yang jauh tempatnya atau banyak jumlahnya.Komunikasi bermedia di sebut juga komunikasi tak langsung (indirect communication) dan sebagai konsekuensinya arus balikpun tidak terjadi pada saat komunikasi dilancarkan.Untk itu komunikasi lewat media bersifat satu arah sehingga sehingga komunikator tidak mengetahui tanggapan komunikan pada saat berkomunikasi.

Pada dasarnya komunikasi dakwah dapat menggunakan berbagai media yang dapat merangsang indra-indra manusia serta dapat menimbulkan perhatian untuk penerima dakwah. Komunikasi dakwah sebenarnya semakin tepat dan efektif media yang dipakai semakin efektif pula upaya pemahaman ajaran islam pada komunikan dakwah. Berdasarkan banyaknya, komunikan yang dijakdikan sasaran dikelasifikasikan menjadi dua , yaitu "media massa" dan "media nirmassa".

${ }^{12} \mathrm{R}$. Masri Sareb Putra, MEDIA CETAK, bagaimana merancang dan memproduksi,(Yokyakarta: Cahaya Ilmu, 2007), 4- 5 
Dakwah merupakan proses mengubah seseorang maupun masyarakat (pemikiran, perasaan, prilaku) dari kondisi yang buruk ke kondisi yang lebih baik. Secara spesifik dakwah Islam diartikan sebagai aktivitas menyeru/ mengajak dalam melakukan perubahan kepada manusia untuk melakukan kema'rufan dan mencegah dari kemungkaran. ${ }^{13}$

Berdasarkan penjelasan di atas, maka seberapa besarnya aktivitas dakwah bisa berhasil secara optimal, jika didukung oleh proses komunikasi yang baik dan efektif. Terkait dengan hal ini, maka komunikator yang juga sekaligus merupakan dai juga harus memperhatikan tampilan diri komunikator.

Retorika seorang dai juga akan mempengaruhi ketertarikan para madu kepada materi yang disampaikan, sehingga ada ungkapan dalam bahasa arab

bahwah strategi atau cara penyampaian atau retorika itu lebih orgen dibandingkan dengan materi yang disampaikan.

Dengan retorika yang baik, maka seorang da'i bisa diterima oleh mad'u sebagai penerima pesan dakwah, begitu juga dengan komunikasi yang disampaikan oleh da'i, karena peran komunikasi dalam dakwah sangatlah berpengaruh dalam merubah objek dakwah, semakin efektif komunikasi dakwah yang sampaikan maka akan efektif pula hasil proses tarbiyyah kepada objek dakwahnya. Diantara peran komunikasi dalam dakwah adalah:

a. komunikasi dapat menciptakan iklim bagi perubahan dengan memasukkan nilai-nilai persuasive islam, sikap mental islam, dan bentuk perilaku islam

b. komunikasi dapat mengajarkan keterampilan-keterampilan pendidikan Islam

c. media massa dapat bertindak sebagai pengganda sumber-sumber daya pengetahuan

d. media massa dapat mengantarkan pengalaman-pengalaman yang dialami diri sendiri sehingga mengurangi biaya psikis dan ekonomis untuk menciptakan keperibadian islami (amar ma'ruf nahyi munkar)

e. komunikasi dapat meningkatkan apresiasi yang merupakan perangsang untuk bertindak secara riil

f. komunikasi dapat membantu masyarakat menemukan islam dan pengetahuan Islam dalam mengatasi perubahan

g. komunikasi dapat membuat orang lebih condong untuk berpartisipasi dalam membuat keputusan di tengah kehidupan masyarakat

h. komunikasi dapat mengubah struktur kekuasaan masyarakat pada masyarakat yang awam kemasyarakatan yang memiliki pengetahuan dan wawasan kepada massa

i. komunikasi dapat menciptakan ummat menjadi loyal terhadap Islam

j. komunikasi memudahkan perencanaan dan implementasi program dan strategi dakwah

k. komunikasi dapat membuat dakwah menjadi proses yang berlangsung secara mandiri (self perpetuating).

Komunikasi dan dakwah merupakan dua kalimat yang menarik untuk dikembangkan dalam wacana keilmuan dalam pengembangan masyarakat

${ }^{13}$ Wahyu Ilaihi, Loc. Cit., .157 
Islam.berkaitan dengan dakwah sebagai sebuah ilmu komunikasi dalam Islam, maka banyak para ahli memberikan definisi tentang dakwah, di antaranya:

1. Menurut Salahuddin Sanusi, yang didefinisikan oleh ustadz Bahiyul Khuli dalam bukunya yang berjudul Tadzkiratud Du'at, dakwah ialah suatu komunikasi yang ditimbulkan dari interaksi antarindividu maupun kelompok manusia yang bertujuan memindahkan umat dari suatu situasi yang negative (zaman jahiliyah) ke situasi yang positif. ${ }^{14}$

Menurut Ibnu Taimiyah, dakwah merupakan suatu proses usaha untuk mengajak agar orang beriman kepada Allah, percaya dan mentaati apa yang telah diberitahukan oleh Rasul serta mengajak agar dalam menyembah kepada Allah seakan-akan melihat-Nya. ${ }^{15}$

M. Quraish Shihab mengatakan dakwah adalah seruan atau ajakan kepada keinsyafan atau usaha mengubah sintuasi kepada sintuasi yang lebih baik dan sempurna, baik terhadap peribadi maupun masyarakat.Perwujudan dakwah bukan sekedar usaha peningkatan pemahaman dalam tingkah laku dan pandangan hidup saja, tetapi menuju sasaran yang lebih luas. Apalagi pada masa sekarang ini, ia harus lebih berperan menuju kepada pelaksanaan ajaran Islam secara lebih menyeluruh dalam berbagai aspek. ${ }^{16}$

Sedangkan M. Natsir menyatakan dakwah adalah usaha-usaha menyerukan dan menyampaikan kepada perorangan manusia dan seluruh ummat manusia konsepsi Islam tentang pandangan dan tujuan hidup manusia di dunia ini, dan yang meliputi al-amar al-ma'ruf an-nahyu an al-munkar dengan berbagai macam cara dan media yang diperbolehkan akhlak dan membimbing pengalamannya dalam perikehidupan bermasyarakat dan bernegara. ${ }^{17}$

A. Hasjmy juga menjelaskan bahwa dakwah Islamiah adalah mengajak orang lain untuk meyaqini dan mengamalkan aqidah dan syariah islamiyyah yang terlebih dahulu di yaqini dan diamalkan oleh pendakwah sendiri. ${ }^{18}$

Dari definisi-definisi di atas dapat ditarik kesimpulan, bahwa pengertian dakwah secara terminologis adalah: segenap usaha manusia beragama Islam yang dilakukan dengan sengaja dan terencana, baik melalui lisan, tulisan dan tulisan untuk merubah suatu kondisi kepada kondisi yang lebih baik untuk memperoleh kebahagiaan di dunia dan di akhirat.

\section{Metode Penelitian}

Untuk mencari dan menemukan data penelitian ini, maka diambil jenis penelitian lapangan dengan menggunakan prosedur-prosedur penelitian yang

${ }^{14}$ Ibid, 40-41

${ }^{15}$ Ibnu Taimiyah, Majmu Al-Fatawa, Juz 15, (Riyadh: Mathobi Ar-Riyadh, 1085). 185

${ }^{16}$ M. Quraish Shihab, Membumikan Al-Quran, fungsi dan peran wahyu dalam kehidupan bermasyarakat, (Bandung: Mizan, 2001), cet. 2, 194

${ }^{17}$ M. Natsir 'Fungsi dakwah perjuangan" dalam Abdul Munir Mulkhan, ideologi gerakan Dakwah, (Yogyakarta: Sipres, 1996), cet. 1, 52

${ }^{18}$ Prof. A. hasjmy, Dustur Dakwah Menurut Al-Quran, (Jakarta: Bulan Bintang, 1884), 
meliputi jenis dan sifat penelitian, metode pengumpulan data serta metode analisa data untuk menarik kesimpulan disertai dengan saran-saran.

1. Jenis Penelitian

Penelitian ini mengambil jenis penelitian lapangan (field research) dengan tujuan untuk meneliti yang menyangkut kasus kelembagaan atau riset kelembagaan dan studi kasus. ${ }^{9}$ Penelitian lapangan atau studi kasus bertujuan untuk mempelajari secara intensif tentang latar belakang keadaan sekarang dan interaksi lingkungan suatu unit sosial, individu, kelompok, lembaga dan masyarakat. ${ }^{20}$ Maksudnya dalam penelitian ini akan menggambarkan kegiatankegiatan dakwah yang dilakukan oleh Majalah Suara Hidayatullah terhadap para pelanggan dan umat Islam dalam pengembangan masyarakat Islam.

Metode penelitian yang digunakan dalam penelitian ini adalah metode survei. Menurut pakar metodologi, "metode survei adalah penyelidikan yang diadakan untuk memperoleh fakta-fakta dari gejala-gejala yang ada dan mencari keterangan-keterangan yang faktual, baik tentang institusi sosial, ekonomi dan politik dari suatu kelompok ataupun daerah". ${ }^{21}$ Sedangkan tujuan dari penelitian survie adalah sebagai berikut:

a. Untuk mencari informasi faktual yang mendetail

b. Untuk mengidentifikasi masalah-masalah atau untuk mendapatkan justifikasi keadaan dan praktek-praktek yang sedang berlangsung

c. Untuk membuat komparasi dan evaluasi

d. Untuk mengetahui apa yang dikerjakan oleh orang-orang lain dalam menangani masalah-masalah atau sintuasi yang sama, agar dapat belajar dari mereka untuk kepentingan pembuatan rencana dan pengambilan keputusan masa depan. ${ }^{22}$

Sifat penelitian

Dilihat dari sifatnya, peneltian ini bersifat diskriptif analitis yaitu suatu penelitian yang bertujuan untuk memberikan gambaran tentang suatu masyarakat atau suatu kelompok orang tartentu atau gambaran suatu gejala atau hubungan antara dua gejala atau lebih yang kemudian dilakukan penilaian yang lebih terurai dan mendalam. ${ }^{23}$ Penelitian ini bersifat deskriptif analisis.Yang dimaksud dengan deskriptif analisis adalah penelitian yang menggambarkan atau mendiskripsikan keadaan suatu objek kemudian menganalisisnya. ${ }^{24}$

Penelitian ini mendiskripsikan peran dakwah yang dilakukan oleh media cetak Suara Hidayatullah dalam mengembangkan masyarakat Islam. Sebagai media cetak di bawah naungan Pesantren Hidayatullah adalah cikal bakal

${ }^{19}$ Sayuti Ali, Metodologi Penelitian Agama, (Jakarta: Raja Grafindo Persada, 2000), 59

${ }^{20}$ Ibid, 59

${ }^{21}$ Moh. Nazir, Metode Penelitian, (Jakarta: Ghalia Indonesia, 1990), 65

22Sumardi Suryabrata, Metodologi Penelitian, (Jakarta: Rajawali Pres, 1990), 7

${ }^{23}$ Irawan Soehartono, Metode Penelitian Sosial , (Bandung: PT. Remaja Rosdakarya, 2002), 35

${ }^{24}$ Sumardi Suryabrata, Metodologi Penelitian, Op. Cit, . 19 
ORMAS Hidayatullah yang sudah pasti memiliki banyak peran strategis dalam mengembangkan masyarakat islam, buktinya sampai saat ini Pesantren Hidayatullah terus berkembang dan telah hadir di seluruh provinsi Indonesia.

2. Populasi dan Sampel

Populasi adalah keseluruhan obyek sebagai sumber data yang memiliki karakteristik tertentu dalam penelitian. ${ }^{25}$ Dalam penelitian ini sebagai populasi adalah pengurus Majalah suara Hidayatullah yang berjumlah 3 orang, pengelola 40, dan pelanggan atau pembaca Majalah suara Hidayatullah wilayah lampung sebanyak 700 orang. Sehingga total semua populasi 743 orang, dari total tersebut akan di sampel dengan menggunakan purposive sampling. Hal ini dilakukan mengingat keterbatasan waktu dan dana yang dimiliki oleh peneliti.

Sedangkan sampel adalah sebagian yang diambil dari populasi. Sampel dapat dilakukan menggunakan dua metode, yakni pengambilan sampel secara acak (random sampling atau probability sampling) dan pengambilan sampel yang bersifat tidak acak, yakni menggunakan pertimbangan-pertimbangan tertentu, contohnya Purposif sampling. ${ }^{26} \mathrm{Hal}$ ini dilakukan karena keterbatasan waktu, tenaga dan biaya, disamping populasi yang banyak jumlahnya tidak memungkinkan untuk mengambil data dari mereka secara keseluruhan.

Adapun sampel diambil berdasarkan berbagai pertimbangan atau dikenal dengan purposive sampling, dengan kecenderungan dari peneliti untuk memilih informan yang dianggap mengetahui informasi dan masalah yang dikaji secara mendalam dan memiliki karakter atau ciri-ciri tertentu, sehingga dapat dipercaya untuk menjadi sumber data yang valid.

Dalam penelitian ini sampel yang diambil dari pengurus Majalah Suara Hidayatullah 3 orang.Sedangkan sampel dari pelanggan atau pembaca Majalah suara Hidayatullah sebanyak 10 orang.Dengan sampel ini diharapkan bisa mendapatkan data-data yang valid sehingga mendapatkan hasil yang optimal.

Dalam penelitian ini ciri-ciri subjek yang peneliti ambil berdasarkan beberapa kreteria, antara lain:

1. Sudah menjadi pelanggan atau pembaca Majalah suara Hidayatullah minimal 3 tahun

2. Telah mengikuti training kader dakwah Hidayatullah.

3. Pengurus aktif di tingkat Pimpinan Wilayah (PW) dan Pimpinan Daerah (PD)

3. Metode Pengumpulan Data

Untuk mengumpulkan atau mendapatkan data yang sebanyakbanyaknya dalam penelitian ini, maka peneliti mengunakan alat pengumpulan data sebagai berikut:

\footnotetext{
${ }^{25}$ Hadari Nawawi, Metode Penelitian Bidang Sosial, (Yogyakarta : Gajah Mada University Press, 1987), 141

${ }^{26}$ Masri Singarimbun, Sofyan Effendi (Editor), Metode Penelitian Survey, Jakarta : LP3ES, 1989), 155
} 
a. Metode Interview

Metode interview adalah metode pengumpulan data dengan jalan tanya jawab sepihak yang dilakukan dengan sistematik dan berlandaskan kepada tujuan penyelidikan. ${ }^{27}$ Teknik interview yang digunakan dalam penelitian ini adalah dalam rangka mengumpulkan data melalui wawancara atau tatap muka langsung. Menurut Marzuki interview adalah mengumpulkan data dengan tanya jawab sepihak, dikerjakan dengan sistematis berdasarkan pada tujuan penelitian. Metode interview yang digunakan adalah metode interview yang mendalam.Metode ini dipakai sebagai metode utama. Teknik menyampaikan pertanyaan adalah dilakukan bebas terpimpin, karena untuk mendapatkan data yang lebih luas dan mendalam maka interview disampaikan dengan cara terpimpin atau sesuai dengan konsep pertanyaan.

Interview ini akan ditujukan kepada para pengurus / pemilik dan para pembaca / pelanggan Majalah Suara Hidayatullah Lampung, agar mampu mendapatkan data atau informasi yang valid.

b. Metode Observasi

Metode observasi adalah pengamatan dan catatan dengan sistematis mengenai gejala-gejala yang diselidiki. 28

Jenis observasi yang digunakan adalah observasi partisipan, dimana peneliti berbaur langsung dengan objek yang akan diteliti.

Metode ini dilakukan sebagai metode pendukung, karena observasi bisa di lakukan ketika proses interview berlangsung, dalam penelitian ini peneliti menggunakan jenis observasi non partisipan, yakni peneliti hanya melakukan pencatatan-pencatan selama beberapa waktu sesuai dengan kebutuhan.

c. Metode Dokumentasi

Metode dokumentasi yaitu mencari data mengenai hal-hal atau variabel yang berupa catatan, transkrip, buku, surat kabar, majalah, notulen rapat, agenda, dan lain sebagainya. ${ }^{29}$

Dalam penelitian ini dokumentasi yang dimaksud adalah dokumentasi-dokumentasi kegiatan dakwah yang dilaksanakan oleh distributor Majalah suara Hidayatullah Lampung.

${ }^{27}$ Sutrisno Hadi, Metodologi Research, (Yokyakarta, Fak. Psikologi UGM , 1989), Jilid

${ }^{28} \mathrm{Ibid}, 142$

${ }^{29}$ Suharsimi Arikunto, Metodologi Research, (Yogyakarta: Andi Offset, 1989), 70 
4. Metode Analisis Data

Pada bagian ini akan dijelaskan mengenai teknik yang digunakan dalam mengambil data dan analisis data. Data primer diperoleh dari hasil wawancara dengan para pengurus / pemilik dan para pembaca / pelanggan majalah Suara Hidayatullah.Selain itu juga beberapa dokumen yang terkait.

Analisis data kualitatif terdiri dari tiga aktifitas yang berlangsung secara bersamaan.Ketiga aktifitas tersebut adalah reduksi data, penyajian data dan penarikan kesimpulan dan pembuktian.Ketiga alur aktifitas tersebut saling keterkaitan satu dengan yang lainnya dalam analisis data.

a. Reduksi data

Aktivitas reduksi data ialah mengelola data mentah yang dikumpulkan dari hasil wawancara, observasi dan angket diringkas dan disistematiskan, agar mudah dipahami dan dicermati oleh pembaca.Reduksi data ini merupakan satu bentuk analisis data sedemikian rupa sehingga kesimpulan akhir dari penelitian dapat dibuat verifikasi. ${ }^{30}$

Dalam hal ini peneliti memproses secara sistematis data-data akurat yang diperoleh terkait dengan kegiatan-kegiatan atau program-program yang dilakukan oleh media cetak suara Hidayatullah dalam rangka pengembangan masyarakat Islam. Sehingga dengan demikian tesis ini akan dapat dipahami dan dicermati secara mudah oleh para pembaca.

b. Penyajian data

Penyajian data dalam penelitian ini adalah dengan menyusun informasi secara baik dan akurat untuk memperoleh beberapa kesimpulan yang valid dan merealisasikan procedural lanjutan. Dengan eksisnya data akurat ini secara otomatis membantu proses yang sedang terjadi, untuk diadakan analisis lebih lanjut, tentunya mengacu pada data yang ada.

c. Penarikan kesimpulan dan pembuktian

Penarikan kesimpulan merupakan bagian dari aktivitas analisis data.Aktivitas ini dimaksudkan untuk memberikan makna terhadap hasil analisis, menjelaskan pola urutan dan mencari hubungan diantara deminsideminsi yang diuraikan. ${ }^{31}$ Di samping itu, kendati data telah disajikan bukan berarti proses analisa data suda Final, akan tetapi masih ada tahapan berikutnya yaitu penarikan kesimpulan dan verifikasi yang merupakan pernyataan singkat sekaligus merupakan jawaban persoalan yang dikemukakan, dengan ungkapan lain adalah hasil temuan penelitian ini betul-betul merupakan karya ilmiyah yang mudah dipahami dan dicermati.

Penelitian ini digolongkan pada penelitian lapangan, data penelitian ini berangkat dari permasalahan-permasalahan yang akan diungkap dalam

\footnotetext{
${ }^{30}$ Imam Suprayogo dan Tobroni, Metodologi Penelitian Agama, (Bandung, Remaja Rosdakarya, 2001), 193

${ }^{31}$ Suharsimi Arikunto, Op. Cit., 311
} 
penelitian ini adalah kegiatan-kegiatan atau program-program yang dilakukan oleh media cetak suara Hidayatullah dan para pelanggannya dalam pengembangan masyarakat Islam. Oleh karena itu, permasalahan itu akan dijawab dengan mendiskripsikan temuan-temuan penelitian berdasarkan jenis data yang telah ditentukan oleh peneliti anatara lain data kualitatif.

Data kualitatif dalam penelitian ini menekankan prosedur penilaian yang menghasilkan data diskriptif berupa kata-kata atau lisan dari orang dan perilaku yang diamati.Dalam hal ini peneliti menafsirkan dan menjelaskan data-data yang diperoleh dari wawancara, observasi dan angket. Maka dengan demikian penelitian ini akan menggambarkan kegiatan-kegiatan yang dilakukan oleh media cetak suara Hidayatullah dan para pelanggan / pembacanya dalam pengembangan masyarakat Islam.

Hasil Penelitian dan Pembahasan

\section{Hasil Penelitian}

Majalah Suara Hidayatullah adalah salah satu pelopor majalah dakwah di Indonesia, selama 23 tahun perjalanannya dengan oplah 54.000.eksemplar setiap bulan (terbit sebulan sekali), kini majalah Suara Hidayatullah telah beredar di seluruh Nusantara, dan dibaca lebih dari 250.000 pembaca. ${ }^{32}$ Ini merupakan bukti bahwa majalah Suara Hidayatullah semakin dipercaya dan mendapat tempat di hati pembaca.

Majalah Suara Hidayatullah sangat jeli dan hati-hati dalam menyajikan informasi peristiwa terkini yang disajikan dalam perspektif Islam, dan diperuntukkan bagi yang membutuhkan pijakan dalam bersikap lebih dewasa khususnya terhadap persoalan ummat Islam.

Majalah Suara Hidayatullah bersikap obyektif, independen, dan tidak memihak, serta selalu menjunjung tinggi nilai -nilai kebenaran.Analisanya pun tajam dan tuntas dalam mengupas persoalan aktual ummat Islam.

1. Profil Majalah Suara Hidayatullah

PT Lentera Jaya Abadi (PT LJA) adalah perusahaan swasta yang dimiliki dan didirikan oleh organisasi massa Islam "Hidayatullah", untuk mengelola majalah Suara Hidayatullah, situs internet Hidayatullah.com serta buletin Jum'at Al-Qalam. Berdasarkan Akta Notaris Siti Masnuroh SH no 30 Tgl 27 Juni 2006, PT LJA berdomisili di Jl Cipinang Cempedak I/14, Jakarta Timur. ${ }^{33}$ Awalnya, sejak terbit tahun 1988, majalah Suara Hidayatullah diterbitkan dan dikelola langsung oleh pengurus Pesantren Hidayatullah Pusat di Balikpapan dan pengurus Pesantren Hidayatullah cabang Surabaya. Kemudian pada tahun 1999 dialihkan pengelolaannya kepada pengurus Yayasan Penerbitan Pers Hidayatullah (YPPH).

\footnotetext{
${ }^{32}$ AR. Direktur Niaga, Wawancara tgl. 22 Februari 2011

${ }^{33} \mathrm{SH}$, Sekretaris Perusahaan. Wawancara Tgl. 18 Februari 2011
} 
Tiras majalah Suara Hidayatullah selama tahun 2009-2010 ini berkisar antara $50.000 \mathrm{~s} / \mathrm{d} 55.000$ eksemplar.Disebarkan ke seluruh Indonesia melalui jaringan kader Hidayatullah yang tinggal di berbagai daerah. ${ }^{34}$

a. Manajemen

Susunan Dewan Direksi PT Lentera Jaya Abadi periode 2010-2014 sebagai berikut: ${ }^{35}$

Direktur Utama : Drs. Hamim Thohari, M.Si

Direktur Produksi : Mahladi, S.Pi

Direktur Niaga : Drs. Abdul Rochim

Direktur Keuangan : Yosep Riana, A.Md

Sekretaris Perusahaan : Saiful Hamiwanto, SP

Komisaris Utama $\quad$ : BM Wibowo, SE

Komisaris : Ir. Elvenus Omar

Komisaris : : Hasan Ibrahim, MM

b. Visi

1) Menjadi majalah Islam yang terdepan dalam memperjuangkan penegakan aqidah tauhid dan penegakan syariat Islam.

2) Menjadi jembatan komunikasi antar lembaga (harakah dan organisasi) Islam, khususnya yang komit pada penegakan aqidah tauhid dan syariat Islam.

c. Positioning Statement

"Majalah masyarakat bertauhid dan bersyariat"

d. Misi

a) Mensosialisasikan pemahaman yang benar tentang ajaran Islam, masyarakat luas.

b) Memperkenalkan lembaga Hidayatullah beserta program-program kegiatannya kepada masyarakat luas.

c) Memperkenalkan berbagai lembaga Islam dan tokoh Islam, beserta pemikiran dan rekam jejaknya (track record) dalam memperjuangkan penegakan aqidah tauhid dan syariat Islam.

d) Menyampaikan kabar berita yang berkaitan dengan kepentingan umum, khususnya umat Islam. ${ }^{36}$

${ }^{34}$ MHL. Direktur Produksi. Wawancara Tgl. 22 Februari 2011

${ }^{35}$ SH. Sekretaris Perusahaan, Wawancara tgl. 18 Februari 2011

${ }^{36}$ Ibid 
e) khususnya tentang aqidah tauhid dan syariat Islam, kepada

e. Target Pembaca:

Segmen pasar yang ditargetkan menjadi pembaca majalah Hidayatullah adalah mereka yang mempunyai karakteristik sbb:

1) Muslim-Muslimah berusia 20-50 tahun

2) Pengeluaran minimal satu juta Rupiah per bulan

3) Pendidikan minimal SMU

4) Sudah mendapatkan pembinaan dasar keislaman menyangkut akidah, menyadari pentingnya penegakan syariat Islam, serta membutuhkan bimbingan hidup berjamaah

5) Mempunyai kebiasaan membaca (reading habit)

6) Ingin menambah pengetahuan keislamannya serta membangun kepribadian Islamnya. ${ }^{37}$

\section{f. Kantor}

PT Lentera Jaya Abadi saat ini memiliki dua kantor :

1) Jakarta: Jl. Cipinang Cempedak I/14, Jakarta Timur.

2) Surabaya: Perumahan Bumi Madina Asri no 48, Jl. Kejawan Putih Tambak, Mulyorejo, Surabaya.

g. Pembaca Majalah suara Hidayatullah berdasarkan:

Di bawah ini akan peneliti uraikan data-data terkait dengan Majalah suara Hidayatullah secara nasional. ${ }^{38}$

1. Jenis Kelamin

\begin{tabular}{|c|c|c|}
\hline No & Jenis Kelamin & Perbandingan \\
\hline 1 & Laki-laki & $65 \%$ \\
\hline 2 & Perempuan & \\
\hline
\end{tabular}

${ }^{37}$ AR. Direktur Niaga, Wawancara tgl. 22 Februari 2011

${ }^{38}$ Diambil dari Pusat dokumentasi (pusdok) Majalah Suara Hidayatullah, Jakarta 
2. Umur

\begin{tabular}{|c|c|c|}
\hline No & Umur & Perbandingan \\
\hline 1 & $20-40$ Tahun & $52 \%$ \\
\hline 2 & 41 s/d 50 Tahun & $32 \%$ \\
\hline 3 & Diatas 50 Tahun & 14 \\
\hline
\end{tabular}

3. Pekerjaan

\begin{tabular}{|c|c|c|}
\hline No & Pekerjaan & Perbandingan \\
\hline 1 & Wiraswasta & $22 \%$ \\
\hline 2 & PNS & $37 \%$ \\
\hline 3 & Pegawai Swasta & $18 \%$ \\
\hline 4 & Mahasiswa / pelajar & $12 \%$ \\
\hline 5 & & \\
& & \\
\hline
\end{tabular}

4. Tingkat Pendidikan

\begin{tabular}{|c|c|c|}
\hline No & Tingkat Pendidikan & Perbandingan \\
\hline 1 & SLTA & $27 \%$ \\
\hline 2 & S I & $40 \%$ \\
\hline 3 & Lain-lain & $33 \%$ \\
\hline
\end{tabular}


5. Tingkat Ekonomi

\begin{tabular}{|c|c|c|}
\hline No & Tingkat Ekonomi & Perbandingan \\
\hline 1 & Lemah & $21 \%$ \\
\hline 2 & Menengah & $42 \%$ \\
\hline 3 & & $37 \%$ \\
\hline
\end{tabular}

\section{Pembahasan}

Penelitian ini dilakukkan pada Majalah Suara Hidayatullah yang didistribusikan di wilayah Lampung.Melalui penelintian ini dapat dilihat bahwa peran dakwah melalui media cetak untuk pengembangan masyarakat Islam sangat signifikan. Berdasarkan hasil penyebaran angket, wawancara dan observasi di lapangan maka diperolehlah hal-hal sebagai berikut:

1. Analisis Peran Media Cetak Suara Hidayatullah untuk Mengembangkan Masyarakat Islam

a. Analisis Peran Media Cetak Sebagai Komunikator

Salah satu peran media massa adalah sebagai komunikator yang mengkomunikasikan atau meninformasikan setiap peristiwa aktual yang terjadi. Dalam hal ini media cetak Majalah suara Hidayatullah berperan dalam mengkomunikasikan / mensosialisasikan program-program pengembangan masyarakat Islam baik di tingkat lokal, nasional bahkan internternasional. Misalkan dalam salah satu rubriknya adalah rubrik ta'aruf dalam rubrik ini senantiasa menginformasikan berbagai sekolah yang berbasis Pondok Pesantren, bahkan dalam beberapa edisi peneliti temukan memuat info pembangunan sekolah Islam di daerah rawan pemurtadan yakni daerah Tomohon, Manado, Sulawesi Selatan, hanya dua edisi naik cetak info tersebut, namun hasilnya sangat memuaskan, pembebasan lahan Pesantren dan pembangunan asrama bisa diselesaikan dengan tepat waktu.

Sebagai media cetak yang diinisiasi oleh Pondok Pesantren maka ada kesan memiliki kecenderungan dalam merealisasikan program pengembangan masyarakat islam berbasis komunitas, yakni dengan memiliki basis Pondok Pesantren. Di mana dalam Pesantren itu dijadikan tempat memperagakan syari'at Islam secara ketat, misalkan semua orang yang berada dalam lingkungan Pesantren itu diwajibkan mengikuti sholat berjama'ah setiap sholat wajib, memberlakukan kedisiplinan dengan harus meminta izin jika berpergian ke luar Pesantren, diwajibkan memakai jilbab bagi muslimah dan sebagainya. 
Dalam pengembangan masyarakat Islam tentu tidak bisa dilakukan sendiri. Akan tetapi memerlukan kerja sama dari semua pihak terutama yang mempunyai komitmen tinggi terhadap penegakan aqidah tauhid dan syariat Islam. Majalah Suara Hidayatullah berperan sebagai jembatan komunikasi antar harakah atau organisasi massa islam yang menghubungkan antara satu pendapat dengan pendapat lainnya meskipun terkadang sangat berbeda.

Dengan menampilkan profil tokoh-tokoh dari berbagai organisasi keislaman memudahkan masing-masing organisasi mengetahui apa yang telah dilakukan antara satu dengan yang lainnya. Dengan semangat ber-fastabiqul khoirot dalam penegakan aqidah tauhid serta syariat Islam maka pengembangan masyarakat Islam akan berjalan dengan pesat dan kejayaan Islam semakin nampak terang di hadapan mata.

\section{b. Peran Media Cetak Sebagi Motivator}

Proses penyampaian pesan dakwah yang disampaikan oleh para da'i akan lebih efektif jika sarana atau medianya tepat terhadap kebutuhan mad'u atau audiens. Seorang da'i dalam menjalankan tugas dakwah adakalanya memiliki rasa cemas bahkan rela dengan kondisi yang terkadang kurang menguntungkan, sehingga seorang da'i juga membutuhkan motivator sebagai usaha untuk menepis perasaan pesimis dalam menjalankan aktivitasnya sebagai da'i.

Dalam hal ini Majalah suara Hidayatullah sangat efektif dijadikan motivator oleh para da'i dalam menjalankan amanah di berbagai daerah terpencil di Indonesia.Selain berperan sebagai alat silaturrahim atau komunikator, juga berperan dalam memotivasi para da'i.dengan membaca Majalah kajian utama dalam Majalah suara Hidayatullah seakan-akan kami sedang membayangkan dalam satu majlis ilmu dengan para Ustadz kami. Hal ini menunjukkan betapa peran kajian utama Majalah ini turut memompa semangat para da’i dalam menjalankan amanah di berbagai daerah.

Injeksi rohaniah harus selalu ada dalam sanubari aktivis dakwah, karena keterbatasan dana dan waktu sehingga bagi para da'i yang bertugas di wilayah pelosok sangat susah untuk mendapatkan materi-materi dakwah. Dengan adanya Majalah ini sangat membantu para da'i dalam menjalankan pembinaan terhadap masyarakat dimanapun ia bertugas.

Begitu juga dampak injeksi motivasi Majalah suara Hidayatullah terhadap pembacanya, banyak di antara mereka yang awalnya hanya pelanggan / pembacanya saja.Kemudian dengan terus belajar tentang orgensinya hidup berjama'ah yang senantiasa di ulas dalam berbagai kajian dalam majalah tersebut, hingga menyatakan bergabung dalam barisan da'i-da’i Hidayatullah dan siap di beri amanah.Berbagai program turut dilucing, misalkan program kuliah da'i mandiri, kuliah 6 bulan ini memfasilitasi para calon da'i dalam mempelajari berbagai ilmu agama secara integral. 
c. Peran Media Cetak Suara Hidayatullah sebagai Fasilitator

Majalah Suara Hidayatullah semakin besar seiring dengan semakin berkembangnya Yayasan Pondok Pesantren Hidayatullah yang tersebar dari Sabang sampai Merauke dan bahkan ada di setiap kabupaten.Setiap kader Hidayatullah yang ditugaskan ke daerah-daerah selalu dibekali dengan Majalah Suara Hidayatullah.Sesuai dengan niat Ustadz Abdullah Said, pendiri Yayasan Pondok Pesantren Hidayatullah sekaligus penggagas terbitnya Majalah Suara Hidayatullah, bahwa majalah ini adalah untuk memfasilitasi para kader yang terjun ke lapangan dakwah.Juga memfasilitasi masyarakat yang ingin mengetahui Pondok Pesantren Hidayatullah lebih jauh dan ingin mengkaji Islam lebih dalam.

Dengan membawa Majalah Suara Hidayatullah para kader yang terjun bebas ke medan dakwah lebih mudah untuk membahasakan visi dan misi yang diembannya kepada para obyek dakwah. Karena visi dan misi antara yayasan Pondok Pesantren Hidayatullah dengan Majalah Suara Hidayatullah sendiri "seiring sejalan".Hal ini memudahkan para kader untuk mengenalkan Hidayatullah kepada para mad'u dan upaya perintisan pondok pesantren Hidayatullah di daerah tersebut lebih mudah.

Selain untuk memfasilitasi para kader pesantren Hidayatullah yang diterjunkan ke medan dakwah, Majalah Suara Hidayatullah juga memfasilitasi organisasi-organisasi Islam lainnya untuk ikut serta dalam mengembangkan masyarakat Islam. Dengan menyajikan informasi-informasi yang berkaitan dengan pengembangan masyarakat berarti mengajak berbagai elemen masyarakat untuk andil dalam berbuat untuk ummat.Beberapa harakah atau organisasi Islam juga memanfaatkan beberapa rubrik di Majalah Suara Hidayatullah untuk menyuarakan pendapat dan pemikirannya yang berkaitan dengan kebenaran Islam.

Dalam majalah Suara Hidayatullah edisi Milad 20 ada seorang pembaca yang mengatakan bahwa dengan membeli majalah Suara Hidayatullah berarti sudah berinfaq di jalan Allah.Bahkan dia bisa mengajak teman-temannya untuk sama-sama berlangganan majalah suara Hidayatullah.Selain itu majalah suara Hidayatullah sendiri mengadakan bedah Kajut (Kajian Utama) untuk umum sehingga masyarakat umum bisa mengambil informasi/ilmu secara lebih gamblang dan mendalam. Dengan kata lain adanya majalah suara Hidayatullah ini bisa memfasilitasi berbagai elemen masyarakat untuk senantiasa berbuat kebajikan dan beramal sebanyakbanyaknya.

2. Analisis Faktor Pendukung dan Penghambat Majalah Suara Hidayatullah dalam Upaya Pengembangan Masyarakat Islam

a. Faktor-faktor Pendukung

Sebagai mana disampaikan oleh Bapak Saiful Hamiwanto dalam wawancara via email bahwa faktor pendukung utama dalam program pengembangan masyarakat islam melalui media cetak suara Hidayatullah 
adalah dikarenakan memiliki jaringan kader di seluruh Indonesia, sehingga proses distribusi dan marketing ke daerah-daerah bisa berjalan efektif. Hampir semua agen Majalah suara Hidayatullah di kelola oleh para kader yang ditempatkan di berbagai daerah Indonesia. Agen-agen Majalah suara Hidayatullah secara umum adalah kader-kader yang sengaja ditugaskan ke berbagai wilayah Indonesia untuk mencoba serta berupaya dalam proses pengembangan masyarakat Islam berbasis pesantren. Sehingga wajar saja kalau Majalah ini bisa eksis ke semua provinsi dan kabupaten kota di seluruh Indonesia. Dan tidak resiko gulung tikar sangat kecil, karena semua pengelola dari top management sampai pada level paling bawa memiliki kesamaan visi terhadap pengembangan masyarakat Islam.

Di samping memiliki jaringan kader yang militan di seluruh Indonesia majalah ini juga memiliki pelanggan yang loyal sangat banyak, sehingga harga yang mahal juga bukan menjadi masalah untuk tidak membaca majalah suara Hidayatullah.Ini terbukti dari lonjakan harga terus terjadi sampai terakhir harga majalah ini mencapai Rp. 23.500 untuk luar jawa.

Kometmen suara Hidayatullah untuk menjadi penengah antar aktivis dakwah tetap dipertahankan oleh para senior lembaga tersebut, hal ini dapat di lihat pada statemennya yakni "jama'tun min jama'atil muslim" bahwa Hidayatullah hadir sebagai bagian dari kelompok kaum muslimin yang konsen pada program tarbiyyah dan da'wah. Sehingga dalam menjalankan aktivitas dakwah bilqolamnya senantiasi mengakomudir semua kelompok lembaga dakwah, hal ini bisa di lihat di beberapa edisi.

b. Faktor-faktor Penghambat

Salah satu faktor penghambat Majalah suara Hidayatullah dalam upaya mengembangkan masyarakat Islam adalah kurangnya dana untuk pengembangan usaha. Sehingga dari sisi pendanaan organisasi kurang maksimal dan banyak program pengembangan masyarakat yang berjalan tersendat-sendat. Tidak dapat di pungkiri bahwa pendanaan merupakan faktor yang orgen dalam mengembangkan berbagai program pengembangan masyarakat islam, sehingga langka-langka untuk mandiri secara finansial harus terus diusahakan sedemikian rupa agar bisa mandiri dan tidak tergantung terhadap unsur-unsur tertentu.

Agar independen maka kemandirian financial dalam sebuah lembaga dakwah merupakan sebuah keharusan, potensi kaum muslimin sungguh sangat besar, namun tidak bisa dipungkiri bahwa potensi - potensi tersebut belum terarah secara optimal. Misalkan tentang pengelolaan dana zakat infaq wakaf dan shodaqoh, walaupun akhir-akhir ini dukungan pemerintah melalui undang undang tentang pengelolaan ZISWAF sudah disahkan. Faktanya dana-dana tersebut masih belum memberikan kontribusi yang signifikan dalam program pengembangan masyarakat islam. Contoh lain tentang pengelolaan tanah wakaf, potensi pengembangan masyarakat Islam melalui tanah wakaf cukup menjanjikan, namun kenyataannya masih banyak tanah wakaf yang belum terkelola dengan baik, hal ini disebabkan oleh kurangnya dana untuk memproduktifkan aset-aset wakaf tersebut. 
Dalam hal ini pemerintah melalui undang-undang juga sudah mengeluarkan fatwa melalui Majlis ulama' Indonesia (MUI) tentang bolehnya atau sahnya berwakaf dengan uang, atau lebih di kenal dengan wakaf tunai, dengan fatwa ini diharapkan bisa memproduktifkan aset-aset wakaf yang belum tergarap dengan baik.

Setiap kader Hidayatullah yang bertugas ke daerah binaan hanya membawa bekal niat yang kuat untuk berjuang di jalan Allah tanpa membawa bekal materiil.Sehingga upaya pengembangan masyarakat Islam tidak mudah dan berjalan lambat.Bahkan fakta di lapangan menunjukkan para kader dakwah tersebut kesulitan membagi waktu antara mencari ma'isyah dan membina ummat.

Dilihat dari segmen pasar majalah Suara Hidayatullah dapat disimpulkan bahwa pembaca majalah ini hanya pada kalangan-kalangan tertentu saja.Majalah suara Hidayatullah tidak dengan mudah ditemukan di pasaran atau toko-toko buku.Sehingga untuk masyarakat umum agak kesulitan untuk membeli majalah suara Hidayatullah.Pendistribusiannya hanya pada para kader Hidayatullah yang ditugaskan di daerah-daerah.Sehingga memberi kesan eksklusif dan tidak menjangkau seluruh lapisan masyarakat.Hal ini hanya bergantung pada kamampuan para kader yang bertugas di daerah tersebut lebih banyak dengan system door to door.

Faktor lainnya masih kurangnya sumber daya insani (SDI) yang professional ini yang menyebabkan di beberapa daerah binaan, sehingga pembinaan ke masyarakat belum bisa optimal. Walaupun ORMAS Hidayatullah telah mendirikan tiga perguruan tinggi gratis, yakni Sekolah Tinggi Ilmu Syari'ah (STIS) di Balikpapan, Sekolah Tinggi Agama Islam Luqman Al-Hakim (STAIL) di Surabaya dan Sekolah Tinggi Ekonomi (STIE Hidayatullah) di Depok. Juga akhir-akhir ini Hidayatullah sebagai organisasi massa membuat gebrakan dengan membuat program-program seperti Kuliah Da'i Mandiri (KDM) yang nanti lulusannya langsung ditugaskan ke daerahdaerah.

Dengan berbagai program ini, diharapkan bisa membuat gerak dakwah semakin cepat, mengingat krisis moral yang terus berkelanjutan, sehingga merasa perlu untuk ambil bagian dalam membina dan mengayomi setiap generasi muda.

\section{Kesimpulan dan Saran}

\section{a. Kesimpuan}

Setelah semua data yang diperlukan dalam penelitian ini terkumpul, kemudian berusaha untuk menganalisis beberapa data yang diperoleh, dan selanjutnya menyimpulkan:

1. Majalah suara Hidayatullah sangat berperan untuk mengembangkan masyarakat Islam dalam kapasitasnya sebagai: komonikator, motivator, stabilator dan fasilitator. 
a. Komunkator yakni mengkomunikasikan / mensosialisasikan programprogram pengembangan masyarakat Islam secara luas. Secara umum peran media adalah untuk membentuk kesepahaman bersama dalam satu permasalahan. Dalam hal ini walaupun belum menyentuh kesemua lapisan, setidaknya kehadiran Pesantren Hidayatullah dari Sabang sampai Meroke dengan jumlah Pondok Pesantren lebihkurang 250, ini membuktkan kesuksesan Majalah suara Hidayatullah dalam mensosialisasikan program-program pengembangan masyarakat Islam berbasis Pondok Pesantren

b. Motivator yakni memberikan motivasi terhadap juru dakwah dan objek dakwah diberbagai daerah terpencil di Indonesia

c. Fasilitator yakni memfasilitasi kaum muslimin, khususnya para jur dakwah dalam upaya pengembangan masyarakat Islam, dan sebagai edukasi terhadap objek dakwah.

2. Faktor pendukung suara Hidayatullah dalam upaya pengembangan masyarakat Islam adalah: jaringan kader yang militan di seluruh Indonesia dan memiliki pelanggan / pembaca yang loyal.

3. Faktor penghambat suara hidayatullah dalam upaya pengembangan masyarakat islam adalah: kurangnya dana untuk mengembangkan amal usaha produktif dan minimnya sumber daya insane (SDI) yang professional

\section{b. Saran}

1. Peneliti merekomendasikan kepada pemerintah bahwa Majalah suara Hidayatullah yang dinaungi oleh PT. Lentera Jaya Abadi perlu diberikan pelatihan dan suntikan dana segar agar dia bisa mengembangkan usaha produktif yang lebih luas, sehingga memiliki dampak terhadap perkembangan masyarakat islam Indonesia yang lebih signifikan lagi.

2. Diharapkan kepada redaksi Majalah suara Hidayatullah dapat terus mengambangkan masyarakat Islam melalui dakwah bil Qolam dan bisa memperluas dakwah tersebut dengan membuka agen-agen baru serta pelayanan-pelayanan keummatan yang lebih luas lagi.

3. Diharapkan Majalah suara Hidayatullah bisa menembus semua lapisan masyarakat, agar target dakwah bil qolam nya lebih banyak memberikan manfaat, sehingga misi Majalah berkeinginan untuk menjadi jembatan antar lembaga dakwah semakin maksimal. 
198 Jurnal Dakwah dan Komunikasi, Vol. 3 No. 2, 2018

\section{Daftar Pustaka}

Aceng Abdullah, Press Relations; Kiat Berbubungan dengan Media Massa, (Bandung: Remaja Rosdakarya, 2001),

Adian Husaini, Penyesatan Opini; Sebuah Rekayasa Mengubah Citra,

Asep Samsul M. Romli, SIP, JURNALISTIK DAKWAH visi dan misi dakwah bil Qalam, (Bandung: Remadja Rosdakarya, 2003)

Hadari Nawawi, Metode Penelitian Bidang Sosial, (Yogyakarta : Gajah Mada University Press, 1987)

Ibnu Taimiyah, Majmu Al-Fatawa, Juz 15, (Riyadh: Mathobi Ar-Riyadh, 1085)

Imam Suprayogo dan Tobroni, Metodologi Penelitian Agama, (Bandung, Remaja Rosdakarya, 2001)

Irawan Soehartono, Metode Penelitian Sosial , (Bandung: PT. Remaja Rosdakarya, 2002)

M. Natsir Fungsi dakwah perjuangan” dalam Abdul Munir Mulkhan, ideologi gerakan Dakwah, (Yogyakarta: Sipres, 1996), cet. 1

M. Quraish Shihab, Membumikan Al-Quran, fungsi dan peran wabyu dalam kehidupan bermasyarakat, (Bandung: Mizan, 2001), cet. 2

Majalah Suara Hidayatullah, Profil Majalab Suara Hidayatullab tabun 2008, edisi 03/XXI / Juli 2008-Jumadil Akhir 1429 / ISSN 0863-2367

Majalah Suara Hidayatullah, Tonggak-tonggak Sejarah majalah Suara Hidayatullah, Edisi khusus Milad 2008,

Manshur Salbu, Mencetak Kader, Perjalanan Hidup Ustadz. Abdullah Said Pendiri Hidayatullah,

Masri Singarimbun, Sofyan Effendi (Editor), Metode Penelitian Survey, Jakarta : LP3ES, 1989)

Moh. Nazir, Metode Penelitian, (Jakarta: Ghalia Indonesia, 1990)

Prof. A. hasjmy, Dustur Dakwah Menurut Al-Quran, (Jakarta: Bulan Bintang, 1884)

R. Masri Sareb Putra, MEDIA CETAK, bagaimana merancang dan memproduksi,(Yokyakarta: Cahaya Ilmu, 2007)

Sayuti Ali, Metodologi Penelitian Agama, (Jakarta: Raja Grafindo Persada, 2000)

Suharsimi Arikunto, Metodologi Research, (Yogyakarta : Andi Offset, 1989) 
Sumardi Suryabrata, Metodologi Penelitian, (Jakarta: Rajawali Pres, 1990)

Sutrisno Hadi, Metodologi Research, (Yokyakarta, Fak. Psikologi UGM , 1989), Jilid 1

Toto Tasmara, Komunikasi Dakwah, (Jakarta: Penerbit Gaya Media Pratama, 1997)

Walter Lippmann, Opini Umum, (Jakarta: Yayasan Obor Indonesia, 1994), 
$200 \mid$ Jurnal Dakwah dan Komunikasi, Vol. 3 No. 2, 2018

Halaman ini sengaja di kosongkan 